Relations industrielles

Industrial Relations

\title{
Braun, Jerome, The Humanized Workplace
}

\section{Hoyt N. Wheeler}

Volume 50, numéro 4, 1995

L'ergonomie et les relations industrielles

Ergonomics and Industrial Relations

URI : https://id.erudit.org/iderudit/051064ar

DOI : https://doi.org/10.7202/051064ar

Aller au sommaire du numéro

\section{Éditeur(s)}

Département des relations industrielles de l'Université Laval

\section{ISSN}

0034-379X (imprimé)

1703-8138 (numérique)

Découvrir la revue

Citer ce compte rendu

Wheeler, H. N. (1995). Compte rendu de [Braun, Jerome, The Humanized Workplace]. Relations industrielles / Industrial Relations, 50(4), 898-900. https://doi.org/10.7202/051064ar

Tous droits réservés (C) Département des relations industrielles de l'Université Laval, 1995
Ce document est protégé par la loi sur le droit d'auteur. L'utilisation des services d'Érudit (y compris la reproduction) est assujettie à sa politique d'utilisation que vous pouvez consulter en ligne.

https://apropos.erudit.org/fr/usagers/politique-dutilisation/ 
professionnelle de jeunes filles impliquées dans divers modes de formation au secrétariat. Mettant en œuvre une démarche de terrain inspirée de la nouvelle école de Chicago, elle aboutit à une " théorie émergente " selon laquelle l'insertion professionnelle est un processus de construction de l'identité professionnelle. Son issue ne dépend pas que de la personne et de son passé mais aussi des incidents de parcours, des opportunités réelles d'emploi auxquelles les stages conduisent. Nicole Lemieux construit une typologie des modes d'insertion observés qu'elle associe à une typologie des identités: identité de métier ou d'entreprise versus identité de substitution. Le plus frappant dans ce travail intéressant est que le travail est et reste une référence essentielle dans la construction de l'identité sociale.

Enfin, Louise Boivin évalue l'évolution de la situation des femmes sur le marché du travail. Son propos souligne que les mesures en leur faveur ne portent pas tous les fruits attendus. En effet, les travailleuses restent cantonnées dans des secteurs traditionnellement " féminins " et dans des postes peu valorisés. De plus, au moment de l'introduction des nouvelles technologies, elles se font parfois exclure par suppression des emplois les moins qualifiés. Cet article est autant un constat de la situation qu'une dénonciation et un appel à y remédier.

En définitive, le lecteur européen, mais aussi québécois ou canadien, trouvera dans ce numéro une excellente introduction à la situation - et dans une moindre mesure à la recherche - québécoise concernant l'emploi, le travail et la formation professionnelle.

\section{CHRISTIAN MAROY Université Catholique de Louvain}

\section{The Humanized Workplace}

by Jerome BRAUN, Westport, CT, Praeger, 1995, 175 p., ISBN 0-275-94915-X.

The words that come most readily to mind upon reading this book are "hodgepodge," and "interesting." This book is comprised largely of what appears to be a series of essays written at different times for different purposes. The connections among them are not always apparent, and there is a good deal of repetition. Yet, sprinkled into this hodgepodge are some intriguing, and perhaps even brilliant, observations. Whether the value of these gem-like parts outweighs the pain of working through the more ordinary whole, is a matter to be judged by each reader.

As the theme of the volume is the humanized workplace in which industrial justice prevails, I will attempt in this review to concentrate on outlining and commenting upon the author's arguments on this subject. A good deal of his analysis, in a variety of ways and places. has to do with stating how to achieve justice in the workplace.

In the Preface, Braun states that competition, so important in American society, is unjust "when one side, for small benefits, expects the other side to suffer great costs." In the first chapter, he draws from a lengthy summary of a book by another author the interesting observation that American unions and managements should concern themselves not so much with the details of means, such as grievance procedures, but instead focus on ends, "eliminating false values and shortsightedness" that prevent attaining industrial justice. Early in the volume, and many times thereafter, Braun argues that fairness is an important, but lost, value in the employment relationship.

Also early in the volume, in Chapter 1 , the author launches into a vigorous 
attack on American managers. This is one of the more entertaining parts of the book but, unfortunately, suffers from a weakness that appears elsewhere - a failure to provide evidence (or even footnotes citing authority) or really compelling arguments in support of his assertions. He may be right that there is indeed a myth of the manager that "management knows best," and a lack of management responsibility for anything but productivity. It may also be true that work standards in America are set according to what a fast worker, not an average worker, can do. It would be nice to have some proof of this. A point that is crucial to his argument is that managers use a "carrot-and-stick" strategy of motivation, promising rewards in the future for the few rather than good working conditions in the present for the many. He opposes this, and sees it and much else that managers do as having less to do with efficiency than with holding onto power.

There are said to be two bases for standards for industrial justice. These are the right of workers to be average (to work at a natural pace), and the need for managers to show sympathy and understanding. This humanized approach is contrasted to the impersonal bureaucratic one that derives from scientific management. It involves the avoidance of constant pressure for a speedup.

How is industrial justice to be insured? The author's answer, other than persuading managers to be better persons, is the use of investigative reporting to reveal to the consuming public that what is occurring is competition of the unjust sort - small gain for it at great cost to workers. In the eyes of this reviewer, this is not a particularly convincing solution to this problem.

Chapter 3, which is probably the most interesting part of the book, starts out by describing the modern workplace as the province of authoritarians who manipulate workers for their own ends. Again, it would be helpful to have some evidence of this. Also, the author does not discuss the new organizational work technologies (teams, etc.) that at least claim to have the aim of changing this. What is to be done about workplace authoritarianism? Abandon "nit-picking little rules," share the dirty work, set standards according to "what can be expected of a reasonable person," and adopt consensus-style management. Work should be restructured according to the capabilities and wishes of individual workers. Basic trust is needed, as is getting rid of the carrot-and-stick method of motivation, which is "useful for donkeys, less useful for people." Braun provides a questionnaire for determining the interests of workers as a step along the way to consultation with them, as well as a practical list of things that might be done to provide fairness and justice in the workplace. He recognizes that attempts to adopt the reforms that he suggests will run into opposition from both managers and workers. At the end of this chapter, he provides some broad conclusions. These include a need for "honesty and treating people as individuals, as whole human beings, with feelings and needs." $\mathrm{He}$ advises against constant pressure for production, and seeing competition as the "end-all and be-all of life." Also, "[T] he problem is usually a matter of greed; people are not concerned about effects that affect others." He provides a checklist for assessing the degree to which work is humanized in an organization.

The balance of the book purports to provide background on the psychological and historical settings of the humanization of work, although this is where the term "hodgepodge" becomes most appropriate. There is a reprint of an article on "Pressuring Institutions and Flat Personalities," a somewhat interesting essay on the "Minimum Wage as a Cultural Construct," a somewhat confusing analysis of status and contract in 
employment, and a discussion of "The Right to be Average." The rationale for the inclusion of a reprint of an admittedly interesting journal article by Schregle on German works councils is neither given nor obvious.

As an introduction to the book, the author quotes Dostoyevsky as to the negative effects of having one's work viewed as completely useless. Hopefully, my criticisms will not lead the reader to reach this conclusion on this book. For my own part, I judge the book to have sufficient virtues to offset its weaknesses, although I am tempted to recommend taking the author's advice in the Preface and read only Chapter 3 . My favourable opinion probably arises from a weakness on my own part for stimulating ideas, of which there is a plentiful supply in this book.

HOYT N. WHEELER

University of South Carolina

\section{Copper Crucible: How the Arizona Miner's Strike Recast Labor-Manage- ment Relations in America}

by Jonathan D. ROSENBLUM, Ithaca, N.Y., ILR Press, 1995, 257 p., ISBN 087546-331-2 (cloth), ISBN 0-87546-332-0 (pbk.).

An image haunts the book Copper Crucible. It's not like the spectre that once haunted Europe, though the Mexican American miners were at times during the history of their relationship with the Phelps Dodge corporation accused of being Communists. The image is a photograph that opens the book. A striker approaches an advancing line of state troopers through a cloud of tear gas. His arms are outstretched in an attitude of crucifixion and he is completely naked.

The subtitle of this excellent book makes a rather large claim. Historians might dispute the absolute centrality of the Phelps Dodge attack among the many powerful blows that both government and corporations directed at organized labour in the 1980 s, but Rosenblum makes a good case. According to the author, it was the implementation by Phelps Dodge of a union busting plan centered on the employment of permanent replacements which was developed by hardline management consultants out of the University of Pennsylvania's Wharton School that marked a turning point in U.S. labour relations.

Whether, it was really the PATCO strike, or the Eastern Airlines struggle (where management showed it was will- ing to destroy a company rather than share real power with its workforce), or the near liquidation of the great union stronghold of Pittsburgh, matters little. The copper strike revealed the extremes that companies would go to assure total domination of their workforce. The picture of Bobby Andazola walking naked toward the massed ranks of riot police from the Arizona Department of Public Safety shouting: "In the name of Lord God, Lord Jehovah, would you do this to your own brothers and sisters" stands as the archetypal image of U.S. labour in the 1980 s.

At the core of the book is a well written account of the bitter strike enriched by extensive interviews of participants from all sides of the dispute. This book is however more than an account of a particularly bitter labour confrontation. The author traces the long antiunion legacy of Phelps Dodge going back beyond the infamous Bigbee deportations of 1917, where twelve hundred workers organized by the IWW were taken by train across the New Mexico state line and simply dropped in the desert. In 1967, a long industry-wide copper strike was only settled by the personal intervention of President Lyndon Johnson. 